\title{
Enzymes involved in vinyl acetate decomposition by Pseudomonas fluorescens PCM 2123 strain
}

\author{
Elżbieta Szczyrba • Izabela Greń • Grażyna Bartelmus
}

Received: 30 June 2012 / Accepted: 8 July 2013 / Published online: 3 August 2013

(C) The Author(s) 2013. This article is published with open access at Springerlink.com

\begin{abstract}
Esterases are widely used in food processing industry, but there is little information concerning enzymes involved in decompositions of esters contributing to pollution of environment. Vinyl acetate (an ester of vinyl alcohol and acetic acid) is a representative of volatile organic compounds (VOCs) in decomposition, of which hydrolyses and oxidoreductases are mainly involved. Their activities under periodically changing conditions of environment are essential for the removal of dangerous VOCs. Esterase and alcohol/aldehyde dehydrogenase activities were determined in crude cell extract from Pseudomonas fluorescens PMC 2123 after vinyl acetate induction. All examined enzymes exhibit their highest activity at $30-35^{\circ} \mathrm{C}$ and $\mathrm{pH}$ 7.0-7.5. Esterase preferably hydrolyzed ester bonds with short fatty chains without plain differences for $\mathrm{C}_{2}$ or $\mathrm{C}_{4}$. Comparison of $\mathrm{Km}$ values for alcohol and aldehyde dehydrogenases for acetaldehyde suggested that this metabolite was preferentially oxidized than reduced. Activity of alcohol dehydrogenase reducing acetaldehyde to ethanol suggested that one mechanism of defense against the elevated concentration of toxic acetaldehyde could be its temporary reduction to ethanol. Esterase activity was inhibited by phenylmethanesulfonyl
\end{abstract}

Electronic supplementary material The online version of this article (doi:10.1007/s12223-013-0268-0) contains supplementary material, which is available to authorized users.

\section{E. Szczyrba}

Institute of Chemical Engineering, Polish Academy of Sciences,

Bałtycka 5, 44-100 Gliwice, Poland

I. Greń $(\bowtie)$

Department of Biochemistry, Faculty of Biology and Environment

Protection, University of Silesia, Jagiellońska 28,

40-032 Katowice, Poland

e-mail: izabela.gren@us.edu.pl

G. Bartelmus

Department of Process Engineering, University of Opole,

Dmowskiego 7-9, 45-365 Opole, Poland fluoride, while $\beta$-mercaptoethanol, dithiothreitol, and ethylenediaminetetraacetic acid had no inhibitor effect. From among metal ions, only $\mathrm{Mg}^{2+}$ and $\mathrm{Fe}^{2+}$ stimulated the cleavage of ester bond.

\section{Introduction}

Vinyl acetate belongs to the group of volatile organic compounds (VOCs). In the industry, it is used for the production of polyvinyl acetate, polyvinyl alcohol, and other polymers which are finally exploited to manufacture building materials, printing inks, plastics, lacquers, or paints (US EPA 2000). Simultaneously, vinyl acetate appears in exhaust gases, and although it itself is not considered to be highly toxic, it is very hazardous in case of skin and eye contact as well as in case of inhalation (ATSDR 1992). When released into the environment (mainly into air), it can be broken down by photochemical pathways involving hydroxyl radicals or ozone (Ferreira et al. 2010; Kaczmarek et al. 2002). Products of its degradation such as, e.g., acetaldehyde are thought to be more toxic (Greń et al. 2009; Nieder et al. 1990).

So far, only few papers focused on vinyl acetate decomposition by microorganisms (Greń et al. 2009; Greń et al. 2011; Hatanaka et al. 1989; Kasperczyk et al. 2007; LaraMayorga et al. 2010; Nieder et al. 1990). Ability to metabolize vinyl acetate depends on the capacity for synthesis of carboxyl esterase (EC 3.1.1.1). There have been published many reports characterizing esterases employed in food processing industry (Castillo et al. 1999; Choi and Lee 2001; Choi et al. 2004; Fenster et al. 2003a, b; Gobbetti et al. 1997a, b; Liu et al. 2001). However, there is a shortage of data concerning properties of vinyl acetate esterase used in waste gases biotreatment technology. Characterization of carboxylesterase from vinyl acetate-assimilating bacterium has been so far described only by Hatanaka et al. (1989). They described three types of esterases in Pseudomonas sp. 
Z2 strain from which only one was involved in the assimilation of vinyl acetate. Apart from the determination of esterase substrate specificity, there were no other studies concerning the optimization of environmental conditions for its activity.

Esterases are described as enzymes catalyzing both cleavage and formation of ester bonds. They hydrolyze the fatty acid esters with short chains and prefer water-soluble substrates like vinyl acetate (Ateslier and Metin 2006). Products of vinyl acetate cleaving by esterase are thought to be further degraded as shown in Fig 1. Because of the toxicity of acetaldehyde, some microorganisms create very simple and efficient mechanism of provisional decline of its concentration. One part of acetaldehyde is directly metabolized, while the second one is temporarily converted into ethanol, which is afterwards metabolized in the opposite reaction to acetaldehyde. Both reactions are catalyzed by the same oxidoreductase (EC 1.1.1.-): alcohol dehydrogenase cooperating with NADH while it reduces acetaldehyde to its alcohol form, or $\mathrm{NAD}^{+}$while it oxidizes ethanol (Fig. 1) (Nieder et al. 1990).

Previously, we described the susceptibility profile of Pseudomonas fluorescens PCM 2123 to vinyl acetate (Greń et al. 2009), as well as its ability to vinyl acetate decomposition (Greń et al. 2011). Kinetics of vinyl acetate biodegradation by PCM 2123 strain and its modeling on the laboratory scale has been studied (Gaszzczak et al. 2010; Kasperczyk et al. 2007; Kasperczyk and Bartelmus 2010). PCM 2123 strain will be used to construct the trickle-bed bioreactor operating at production scale to purify the outlet gases, and therefore it must be able to perform vinyl acetate decomposition under changeable environmental conditions. The aim of these studies was to determine the optimal conditions for activities of esterase as the essential enzyme in degradation of vinyl acetate by P. fluorescens PCM 2123. Activities of dehydrogenases involved in subsequent metabolism of products of ester bond cleavage were also verified.

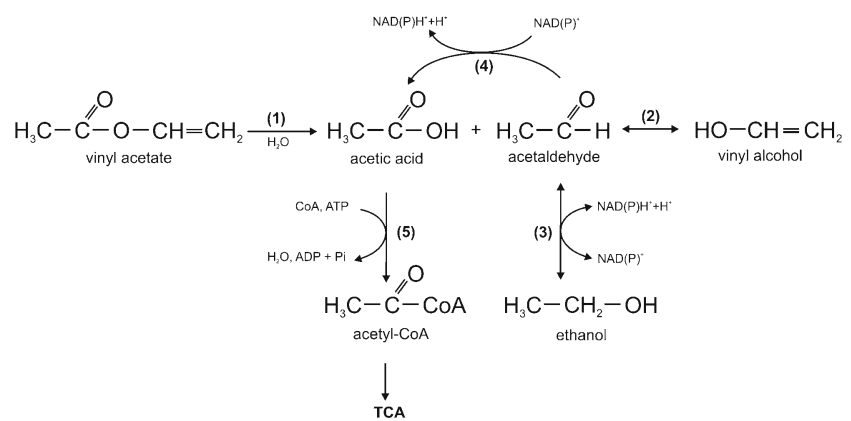

Fig. 1 Proposed pathway of vinyl acetate degradation in P. fluorescens PCM 2123 cells, where: (1) carboxylesterase, (2) tautomerization (chemical process), (3) alcohol dehydrogenase, (4) aldehyde dehydrogenase, (5) acetylo-CoA synthetase, TCA tricarboxylic acid cycle (Nieder et al. 1990, modified)

\section{Materials and methods}

Bacterial strain, growth conditions, and preparation of crude enzyme extract

P. fluorescens PCM 2123 was obtained from The Polish Collection of Microorganisms (Wrocław). Bacteria were grown in mineral medium, and its composition was described previously (Greń et al. 2009). Vinyl acetate in concentration of $0.4 \mathrm{~g} / \mathrm{L}$ was added to the culture every $24 \mathrm{~h}$ as a source of carbon and energy. The strain was grown aerobically for 5 to 7 days in a shaker at $130 \mathrm{rpm}$ at $30{ }^{\circ} \mathrm{C}$ in $500 \mathrm{~mL}$ Erlenmeyer flasks. Cells were harvested in the late exponential phase as performed in Greń et al. (2011). The protein concentration was estimated using the Bradford method with lysozyme as a standard (Bradford 1976).

\section{Enzyme assays}

Esterase activity was determined spectrophotometrically using $p$-nitrophenyl butyrate ( $p$ NPB) or $p$-nitrophenyl acetate ( $p$ NPA) as described previously (Greń et al. 2011). Dehydrogenase activities were determined spectrophotometrically, as it was presented earlier (Greń et al. 2011). Each measurement was performed in triplicates. One unit (U) of esterase activity was defined as the amount of enzyme releasing $1 \mu \mathrm{mol}$ of $p$-nitrophenol per minute under assay conditions.

\section{Effect of temperature on enzyme activity}

The temperature dependence on the esterase activity was determined in $50 \mathrm{mmol} / \mathrm{L}$ phosphate buffer, $\mathrm{pH} 7.5$, in the range $5-50{ }^{\circ} \mathrm{C}$ at every $5{ }^{\circ} \mathrm{C}$. Buffer was preincubated at the examined temperature, and reaction was started by substrate addition.

Dehydrogenase activity was examined in the same buffer at various temperatures from 5 to $40{ }^{\circ} \mathrm{C}$ at every $5{ }^{\circ} \mathrm{C}$.

\section{Thermostability}

The enzyme was preincubated in temperatures between 5 and $65{ }^{\circ} \mathrm{C}$ at every $5{ }^{\circ} \mathrm{C}$ for $30 \mathrm{~min}$. After incubation, samples were cooled on ice, centrifuged, and the remaining activity was measured with $p$ NPB as a substrate. As a control $(100 \%)$, the initial activity of enzyme measured in standard conditions was used.

\section{Determination of $\mathrm{pH}$ optimum}

The effect of $\mathrm{pH}$ on enzymes activity was determined by measuring activity at $30{ }^{\circ} \mathrm{C}$ over $\mathrm{pH}$ range of $4.0-8.0$ using 
$0.05 \mathrm{~mol} / \mathrm{L}$ phosphate-citrate $(\mathrm{pH} 3.0-5.0)$ and $0.05 \mathrm{~mol} / \mathrm{L}$ Sörensen (pH 6.0-8.0) buffer.

pH stability

Crude enzyme extract was preincubated for $30 \mathrm{~min}$ at $30^{\circ} \mathrm{C}$ in buffers of the different $\mathrm{pH}$ in the range of 3.0-8.0. After incubation, samples were cooled on ice, centrifuged, and the residual activity was measured using $p$ NPB. As a control $(100 \%)$, the initial activity of enzyme measured in standard conditions was used.

\section{Enzyme kinetics}

Measurements were performed under standard conditions using various concentrations from 0.025 to $2 \mathrm{mmol} / \mathrm{L}$ of $p$ NPA or $p$ NPB. The crude cell extract was incubated with various concentration of acetaldehyde for aldehyde/alcohol dehydrogenase to give final substrate concentrations in the range of 0.01 to $0.5 \mathrm{mmol} / \mathrm{L}$ or ethanol for alcohol dehydrogenase in the range of 0.01 to $2.5 \mathrm{mmol} / \mathrm{L}$.

Michaelis-Menten constant $(\mathrm{Km})$ and the maximum velocity of the reactions were calculated from a LineweaverBurk plot (Table 1).

\section{Substrate specificity}

Different esters: $p \mathrm{NPB}, p \mathrm{NPA}$ (in DMSO), or $p$-nitrophenyl palmitate ( $p$ NPP) (in acetone) were tested for esterase activity. The measurements were performed under standard assay conditions.

\section{Effect of metal ions}

The crude enzyme extract was preincubated for $30 \mathrm{~min}$ at $30{ }^{\circ} \mathrm{C}$ with $1 \mathrm{mmol} / \mathrm{L}$ various metal ions solutions (Table 2). Residual esterase activity was measured under standard conditions with $p$ NPB as a substrate. As a control (100\%),

Table 1 Kinetics parameters of enzymes activities involved in vinyl acetate decomposition

\begin{tabular}{llll}
\hline Enzyme & Substrate & Vmax (mU/mg protein) & $\mathrm{Km}(\mathrm{mmol} / \mathrm{L})$ \\
\hline Esterase & & 150 & 0.045 \\
& $p \mathrm{NPA}$ & 116 & 0.058 \\
& $p \mathrm{NPB}$ & & 0.022 \\
Alcohol dehydrogenase & & 0.3 \\
Ethanol & 68 & \\
Ethanal & 112 & 0.057 \\
Aldehyde dehydrogenase & & \\
Ethanal & 286 &
\end{tabular}

activity of enzyme after incubation without any metal ion was used.

\section{Effect of inhibitors}

The crude enzyme extract was preincubated for $30 \mathrm{~min}$ at $30{ }^{\circ} \mathrm{C}$ in $1 \mathrm{mmol} / \mathrm{L}$ solutions of different inhibitors (Table 3 ), apart from phenylmethanesulfonyl fluoride (PMSF) that was prepared in three different concentrations: 0.1, 1, and $5 \mathrm{mmol} / \mathrm{L}$. The remaining activity was determined under standard conditions with $p$ NPB as a substrate. As a control, (100\%) activity of enzyme after incubation without any potential inhibitor was used.

Chemicals

Analytical reagent grade chemicals were obtained from Sigma (St Louis, MO, USA), Merck (Darmstadt, Germany), Fluka (Buchs, Switzerland), or POCh (Gliwice, Poland).

\section{Results and discussion}

Effect of temperature on enzyme activity and stability

The esterase showed maximum activity at temperature $35^{\circ} \mathrm{C}$ nevertheless of substrate used in reaction mixture (Table 4, Supplement). When temperature dropped to about $20{ }^{\circ} \mathrm{C}$, esterase exhibited 20-35\% of its maximal activity (Fig. 2a). Similar results were obtained by Castillo et al. (1999) for Lactobacillus casei subsp. casei IFLP31 with optimal temperature at $25-30{ }^{\circ} \mathrm{C}$ and Gobbetti et al. 1997b for Lactobacillus fermentum DT41 with optimal temperatures of esterase activity at $30-35^{\circ} \mathrm{C}$. On the other hand, Ateslier and Metin (2006) described strain Bacillus sp. 4 with optimal growth and esterase production at $65{ }^{\circ} \mathrm{C}$. Enzymes exhibiting stability in high temperatures are supposed to be more proper for harsh conditions of industrial processes, but on the other hand, their activities are relatively low at room temperature, which is sometimes required for chemicals labile in higher temperature like, e.g., vinyl acetate (Zamost et al. 1991).

The optima temperatures for activities of dehydrogenases from PCM 2123 cells were at $30{ }^{\circ} \mathrm{C}$ (Fig. 3a), and an aldehyde dehydrogenase was the only one which lost almost $80 \%$ of its activity when temperature decreased to $20^{\circ} \mathrm{C}$.

The results referring to thermostability of esterase from PCM 2123 cells showed that enzyme is stable (relative activity higher near $80 \%$ ) at temperature from 5 to $35^{\circ} \mathrm{C}$, and above $50^{\circ} \mathrm{C}$, its activity decreases sharply (Fig. 2b). The similar method of testing esterase thermostability was used by Sana et al. (2007), but preincubation time was prolonged 
Table 2 Effect of metal ions (concentration $1 \mathrm{mmol} / \mathrm{L}$ ) on the activity of vinyl acetate esterase

\begin{tabular}{ll}
\hline Metal ion (salts) & Residual activity (\%) \\
\hline None & 100 \\
$\mathrm{Zn}^{2+}{ }_{1}$ & 87 \\
$\mathrm{Mg}^{2+}{ }_{2}$ & 121 \\
$\mathrm{Al}^{3+}{ }_{1}$ & 89 \\
$\mathrm{Ca}^{2+}{ }_{1}$ & 96 \\
$\mathrm{Cd}^{2+}{ }_{1}$ & 99 \\
$\mathrm{Mn}^{2+}{ }_{3}$ & 89 \\
$\mathrm{Hg}^{2+}{ }_{1}$ & 87 \\
$\mathrm{Ni}^{2+}{ }_{1}$ & 95 \\
$\mathrm{Fe}^{2+}{ }_{2}$ & 180 \\
\hline
\end{tabular}

1 added as chloride

2 added as monohydrate chloride

3 added as monohydrate sulfate (VI)

to $1 \mathrm{~h}$. Esterase from a salt-tolerant Bacillus sp. strain BSE01 showed no difference in activity up to $50{ }^{\circ} \mathrm{C}$, and it is more stable at higher temperature than the esterase isolated from strain PCM 2123. Thermostable enzymes like esterase described by Sobek and Görisch (1988) from thermophilic archaebacterium Sulfolobus acidocaldarius lost only $8 \%$ of its activity at $90{ }^{\circ} \mathrm{C}$ and $50 \%$ at $100{ }^{\circ} \mathrm{C}$.

\section{Determination of $\mathrm{pH}$ optima and $\mathrm{pH}$ stability}

The $\mathrm{pH}$ optimum of esterase (Fig. 4a) was about $\mathrm{pH} 7.5$, and dehydrogenases showed the highest activities also in the $\mathrm{pH}$ close to neutral (Fig. 3b). When $\mathrm{pH}$ of environment was increased to 10 , the activity of esterase dramatically decreased (data not shown). The esterase shows a slightly higher activity in the presence of $p$ NPB than $p$ NPA at different $\mathrm{pH}$ (Fig. 4a). The relative activity of the enzyme was higher than $70 \%$ at $\mathrm{pH}$ from 7.4 to 8 for $p$ NPB and at $\mathrm{pH}$ from 7.2 to 7.8 for $p$ NPA. Similar results were observed for esterases isolated from numerous microorganisms, e.g., L. casei subsp. casei IFLP31,

Table 3 Effect of inhibitors on the activity of vinyl acetate esterase

\begin{tabular}{lll}
\hline Chemicals & Concentration(mmol/L) & Relative activity (\%) \\
\hline None & - & 100 \\
PMSF & 0.1 & 38 \\
PMSF & 1 & 16 \\
PMSF & 5 & 0 \\
$\beta$-ME & 1 & 144 \\
Tween 80 & 1 & 159 \\
DTT & 1 & 141 \\
Triton X-100 & 1 & 114 \\
EDTA & 1 & 159 \\
\hline
\end{tabular}

with pH optimum about 7.5 (Castillo et al. 1999) or from Bacillus species - optimal pH about 6.0 (Ateslier and Metin 2006). It is thought that esterases show the highest activity at neutral $\mathrm{pH}$, and this property distinguish them from lipases, which are most active at $\mathrm{pH}$ above 8 (Ateslier and Metin 2006).

The first step of testing $\mathrm{pH}$ stability of esterase from PCM 2123 cells was preincubation of crude cell extract in buffers of different $\mathrm{pH}$ (Fig. 4b). The activity of esterase in the $\mathrm{pH}$ range from 3.0 to 7.0 was relatively stable, although it increased when $\mathrm{pH}$ rose above 8 , which was described for thermophilic Bacillus sp. by Ateslier and Metin (2006). They suggest that the highest activity at $\mathrm{pH} 9$ or 10 could be connected with the presence of some proteases in the crude enzyme extracts. These proteases probably exhibit high activity at $\mathrm{pH} 7.5$ and digest the esterase causing decrease of its activity. While the $\mathrm{pH}$ value of environment reaction rises, the activity of proteases is reduced.

\section{Enzyme kinetics}

The kinetic parameters of vinyl acetate esterase like the Michaelis-Menten constant $(\mathrm{Km})$ and velocity for the
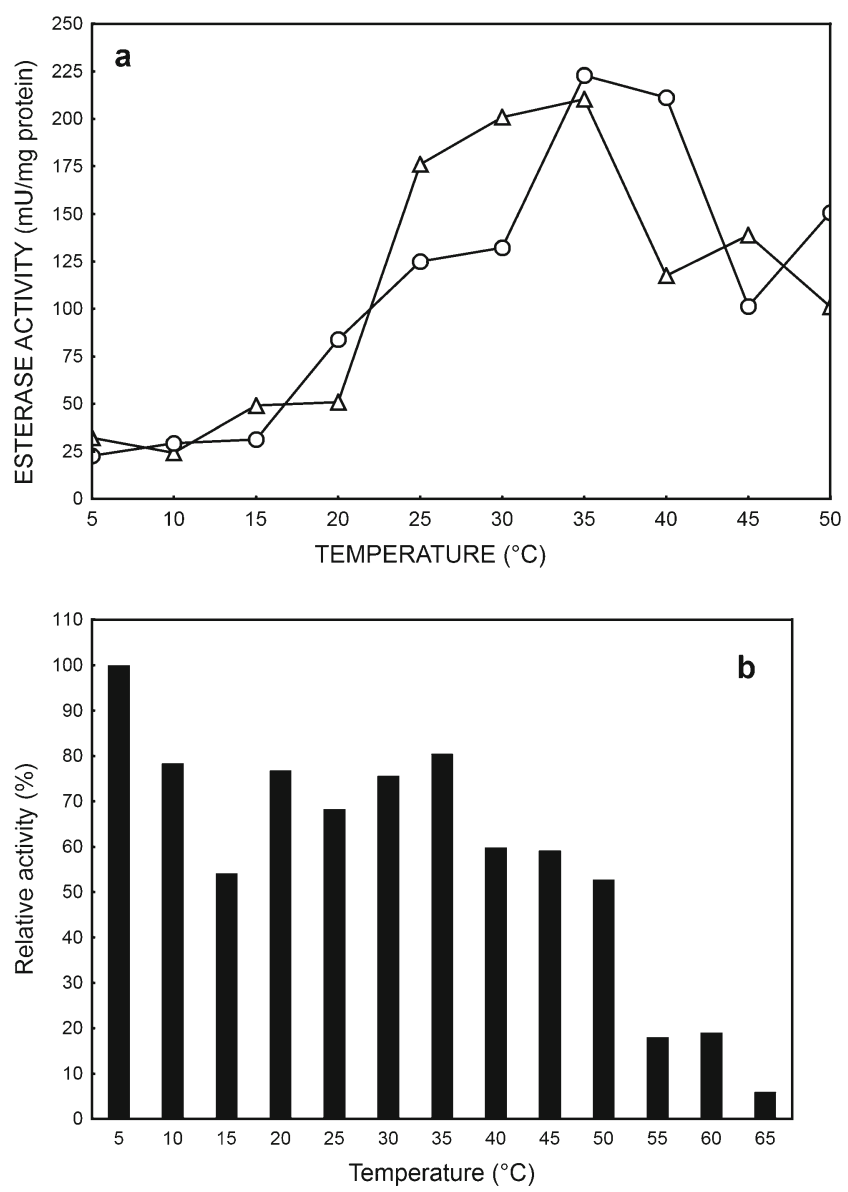

Fig. 2 Effect of temperature (a) and temperature stabilization (b) on esterase activity from PCM 2123 cells, where as a substrate in reaction mixture was used: $p$ NPB (open triangle) or $p$ NPA (open circle) 
reaction $\left(\mathrm{V}_{\max }\right)$ were estimated to be, respectively, $0.045 \mathrm{mmol} / \mathrm{L}$ and $150 \mathrm{mU} / \mathrm{mg}$ protein for $p \mathrm{NPA}$ and $0.058 \mathrm{mmol} / \mathrm{L}$ and $116 \mathrm{mU} / \mathrm{mg}$ protein for $p$ NPB (Table 1). Shortage of data concerning kinetics of vinyl acetate by other microorganisms makes some difficulties to compare these data with the others. The $\mathrm{Km}$ value seems to be similar to the other esterases, e.g., from Bacillus sp. 4, it was $62.89 \mu \mathrm{mol} / \mathrm{L}$ (Ateslier and Metin 2006) or from L. casei LILA, it was $97 \mu \mathrm{mol} / \mathrm{L}$ (Fenster et al. 2003a), when $p$-nitrophenyl butyrate as a substrate were used. It has been previously shown that for numerous industrially relevant enzymes, $\mathrm{Km}$ values are in the range of $10^{-1}$ to $10^{-5} \mathrm{~mol} / \mathrm{L}$ (Fullbrook 1996). Maximal velocities $\left(\mathrm{V}_{\max }\right)$ of reactions catalyzed by esterases are of different values. Some of them exceeded the results for vinyl acetate esterase from PCM 2123 strain, e.g., $\mathrm{V}_{\max }$ of esterase isolated from Bacillus sp. 4 was $833.33 \mathrm{mU} / \mathrm{mg}$ protein, when $p$ NPB was used as a substrate (Ateslier and Metin 2006), or they are of the same value or lower (Castillo et al. 1999; Fenster et al. 2003a; Yang and Liu 2008). Km and $V_{\max }$ values for both oxidoreductases involved in the metabolism of vinyl acetate products were also determined (Table 1). The
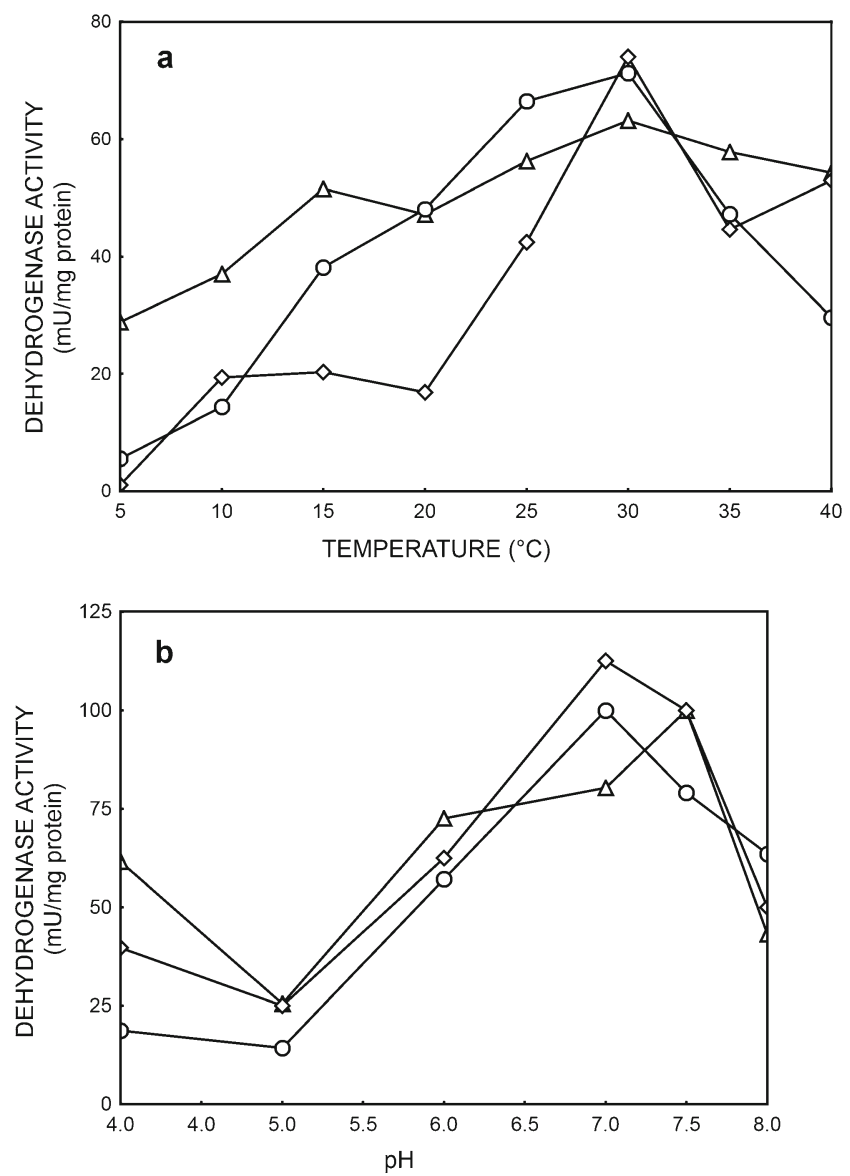

Fig. 3 Effect of temperature (a) and $\mathrm{pH}$ (b) on specific activities of dehydrogenase from PCM 2123 cells, where: alcohol dehydrogenase (ethanol) (open triangle), alcohol dehydrogenase (acetaldehyde) (open circle), aldehyde dehydrogenase (open diamond) highest $\mathrm{V}_{\max }$ for alcohol dehydrogenase was determined, when acetaldehyde was used as a substrate in the reaction mixture. Comparison of $\mathrm{Km}$ values for alcohol and aldehyde dehydrogenases for acetaldehyde suggests that this metabolite of vinyl acetate decomposition will be preferentially oxidized than reduced. Activity of alcohol dehydrogenase reducing acetaldehyde to ethanol confirms our suggestions that one mechanism of defense against elevated concentrations of toxic acetaldehyde can be its temporary reduction to ethanol.

Substrate specificity

In order to estimate the substrate specificity of esterase, the following chemicals: $p$ NPA $\left(\mathrm{C}_{2}\right), p \operatorname{NPB}\left(\mathrm{C}_{4}\right)$, or $p \mathrm{NPP}\left(\mathrm{C}_{16}\right)$ were added to the reaction mixture. It was observed that esterase was active for short-chain fatty acid substrates like $p$ NPB $(192.77 \pm 42.18 \mathrm{mU} / \mathrm{mg}$ protein $)$ and $p$ NPA $(147.15 \pm 31.11 \mathrm{mU} / \mathrm{mg}$ protein), and it completely lost its activity for $p$ NPP. Statistical analysis did not show any significant difference for vinyl acetate esterase with
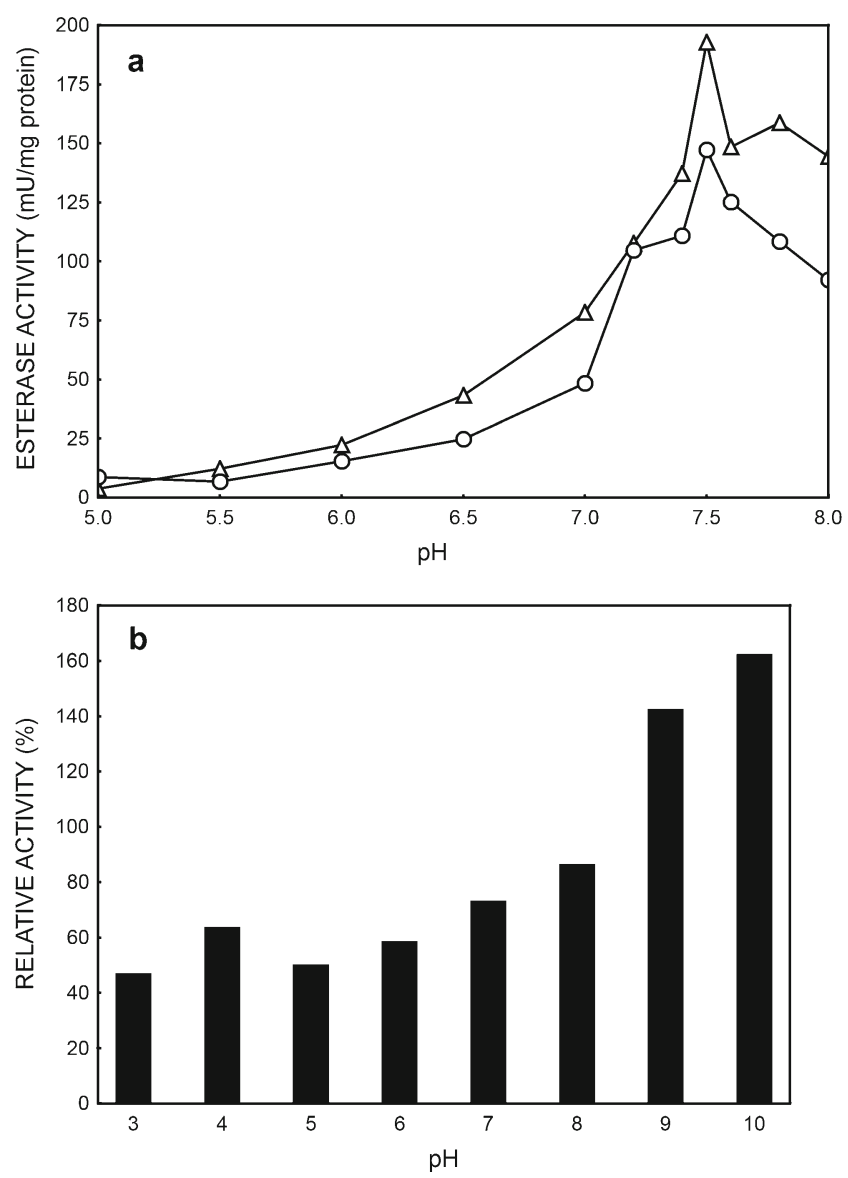

Fig. 4 Effect of $\mathrm{pH}$ (a) and $\mathrm{pH}$ stabilization (b) on esterase specific activity from PCM 2123 cells, where as a substrate in reaction mixture was used: $p$ NPB (open triangle) or $p$ NPA (open circle) 
$p$ NPB or $p$ NPA as a substrate. These results are similar to that obtained for the other described esterases (Ateslier and Metin 2006; Fenster et al. 2003a; Gobbetti et al. 1997a; Kim et al. 2006; Liu et al. 2001; Sobek and Görisch 1988), and are characteristic for hydrolyzes belonging to esterases usually hydrolyzing esters with short-chain fatty acid $\left(\mathrm{C}_{2}\right.$ to $\left.\mathrm{C}_{4}\right)$. Only recombinant esterase from $L$. casei CL96 described by Choi and Lee (2001) showed the major activity for fatty acid esters containing $\mathrm{C}_{6}$ and $\mathrm{C}_{8}$.

\section{Effect of effectors on esterase activity}

Assays to determine the effects of metal ions on esterase activity, using $p$ NPB as a substrate, showed that various metal ions influence in different way on the activity of vinyl acetate esterase (Table 2). $\mathrm{Mg}^{2+}$ and $\mathrm{Fe}^{2+}$ were found to stimulate its activity. Esterase from L. fermentum DT41 also revealed higher activity in the presence of $\mathrm{Mg}^{2+}$, but $\mathrm{Fe}^{2+}$ ion inhibited esterase activity (Gobbetti et al. 1997b). There was no influence of $\mathrm{Ni}^{2+}$, $\mathrm{Ca}^{2+}, \mathrm{Cd}^{2+}$ ions on vinyl acetate esterase from PCM 2123 cells; however, $\mathrm{Ca}^{2+}$ was found to slightly enhance (Choi et al. 2004; Gobbetti et al. 1997b; Tekedar and Sanli-Mohamed 2011) or inhibit (Castillo et al. 1999) activity of this type of enzyme. Other examined ions like $\mathrm{Zn}^{2+}, \mathrm{Al}^{3+}, \mathrm{Mn}^{2+}$, and $\mathrm{Hg}^{2+}$ slightly inhibited the esterase, although the $\mathrm{Hg}^{2+}$ ion is usually the strong inhibitor of esterases because of the reaction with thiol groups (Choi et al. 2004; Gobbetti et al. 1997b).

The vinyl acetate esterase showed higher activity in the presence of reducing agent like DTT, $\beta$-mercaptoethanol ( $\beta$ ME), and EDTA. These results are similar to those obtained by Tekedar and Sanli-Mohamed (2011) for esterases isolated from three different Geobacillus strains. However, these chemicals usually cause decrease of enzyme activity or even total inhibition. The $\beta$-ME reacts with sulfhydryl groups and disulfide bonds existing in catalytic side, and thanks to them, the active conformation of enzyme could be maintained, and the presence of $\beta-\mathrm{ME}$ in the reaction mixture causes decrease of its activity (Choi et al. 2004; Yang and Liu 2008). Our data suggest that thiol groups were not present or were not essential for the catalytic activity if vinyl acetate esterase from $P$. fluorescens.

The examined esterase was resistant to some detergents like Triton X-100 and showed typical for esterases property to be strongly inhibited by PMSF known as a serine inhibitor (Table 3). This is connected with the presence a serine residue in catalytic side, what could be observed equally in lipases and esterases, but lipase possess a characteristic lid, which cover the active side, and makes it resistant to PMSF. The esterases do not have this hydrophobic domain, so they are strongly inhibited by PMSF even in low concentration (Ateslier and Metin 2006; Castillo et al. 1999; Gobbetti et al. 1997a, b; Sana et al. 2007; Smacchi et al. 2000).
These results suggest that the examined enzymes of vinyl acetate biodegradation pathway in PCM 2123 cells, and especially vinyl acetate esterase, exhibit catalytic activities under changeable conditions. Determination of optimal conditions for enzymes activities designates $P$. fluorescens PCM 2123 for some biotechnological application, especially for vinyl acetate removing from exhausted gases, even when the harsh conditions will appear.

Acknowledgments The present research was supported financially by The National Center for Research and Development (NCBiR), grant 1066/R/TO2/2010/10.

Open Access This article is distributed under the terms of the Creative Commons Attribution License which permits any use, distribution, and reproduction in any medium, provided the original author(s) and the source are credited.

\section{References}

Agency for Toxic Substances and Disease Registry (ATSDR) 1992 Toxicological profile for vinyl acetate. http://www.atsdr.cdc.gov/ toxprofiles/tp.asp?id=671\&tid=124. Accessed 15 May 2012

Ateslier ZBB, Metin K (2006) Production and partial characterization of novel thermostable esterase from a thermophilic Bacillus sp. Enzyme Microb Technol 38:628-635

Bradford MM (1976) A rapid and sensitive method for the quantitation of microgram quantities of protein utilizing the principle of protein-dye binding. Anal Biochem 72:248-258

Castillo I, Requena T, Fernandez de Palencia P, Fontecha J, Gobbetti M (1999) Isolation and characterization of intracellular esterase from Lactobacillus casei subsp. casei IFPL731. J App Microbiol 86:653-659. doi:10.1046/j.1365-2672.1999.00708.x

Choi YJ, Lee BH (2001) Culture conditions for the production of esterase from Lactobacillus casei CL96. Bioprocess Biosyst Eng 24:59-63. doi:10.1007/S004490100233

Choi YJ, Miguez CB, Lee BH (2004) Characterization and heterologous gene expression of a novel esterase from Lactobacillus casei CL96. Appl Environ Microbiol 70:3213-3221. doi:10.1128/ AEM.70.6.3213-3221.2004

Fenster KM, Parkin KL, Steele JL (2003a) Intracellular esterase from Lactobacillus casei LILA: nucleotide sequencing, purification, and characterization. J Dairy Sci 86:1118-1129

Fenster KM, Parkin KL, Steele JL (2003b) Nucleotide sequencing, purification, and biochemical properties of an arylesterase from Lactobacillus casei LILA. J Dairy Sci 86:2547-2557

Ferreira JL, Melo MJ, Ramos AM (2010) Poly(vinyl acetate) paints in works of art: a photochemical approach. Part 1. Polym Deg Stab 95:453-461

Fullbrook PD (1996) Practical applied kinetics. In: Godfrey T, West S (eds) Industrial enzymology, 2nd edn. Stockton, New York, pp $483-540$

Gąszczak A, Szczyrba E, Bartelmus G (2010) Badania kinetyki reakcji biodegradacji lotnych związków organicznych na przykładzie octanu winylu. Inż Ap Chem 1:41-42 [In Polish]

Gobbetti M, Fox PF, Stepaniak L (1997a) Isolation and characterization of tributyrin esterase from Lactobacillus plantarum 2739. J Dairy Sci 80:3099-3106

Gobbetti M, Smacchi E, Corsetti A (1997b) Purification and characterization of a cell surface-associated esterase from Lactobacillus fermentum DT41. Int Dairy J 7:13-21 
Greń I, Gąszczak A, Szczyrba E, Łabużek S (2009) Enrichment, isolation, and susceptibility profile to the growth substrate of bacterial strains able to degrade vinyl acetate. Pol J Environ Stud 18:383390

Greń I, Gąszczak A, Guzik U, Bartelmus G, Łabużek S (2011) A comparative study of biodegradation of vinyl acetate by environmental strains. Ann Microbiol 61:257-265. doi:10.1007/s13213010-0130-4

Hatanaka Y, Inoue Y, Murata K, Kimura (1989) A isolation and characterization of carboxylesterase from vinyl acetateassimilating bacterium isolated from soil. J Ferment Bioeng 67:14-19

Kaczmarek H, Drag R, Świątek M, Ołdak D (2002) The influence of UV-irradiation on poly(vinyl chloride) modified by poly(vinyl acetate). Surf Sci 507-510:877-882

Kasperczyk D, Bartelmus G (2010) Purification processes - Biodegradation of vinyl acetate from waste air in a trickle-bed bioreactor (TBB). Chem Eng Transc 21:595-600

Kasperczyk D, Bartelmus G, Gaszczak A (2007) Clean processes — biodegradation kinetics and mathematical modeling of microbial removal of vinyl acetate from dilute gaseous waste streams. Chem Eng Transc 11:665-670

Kim YJ, Choi GS, Kim SB, Yoon GS, Kim YS, Ryu YW (2006) Screening and characterization of a novel esterase from metagenomic library. Protein Expression Purif 45:315-323. doi:10.1016/j.pep.2005.06.008

Lara-Mayorga I, Durán-Hinojosa U, Arana-Cuenca A, MonroyHermosillo O, Ramírez-Vives F (2010) Vinyl acetate degradation by Brevibacillus agri isolated from a slightly aerated methanogenic reactor. Environ Technol 31:1-6. doi:10.1080/09593330903260904
Liu SQ, Holland R, Crow VL (2001) Purification and properties of intracellular esterases from Streptococcus thermophilus. Int Dairy J 11:27-35

Nieder M, Sunarko B, Meyer O (1990) Degradation of vinyl acetate by soil, sewage, sludge, and the newly isolated aerobic bacterium V2. Appl Environ Microbiol 56:3023-3028

Sana B, Ghosh D, Saha M, Mukherjee J (2007) Purification and characterization of extremely dimethylosulfoxide tolerant esterase from salt-tolerant Bacillus species isolated from the marine environment of the Sundarbans. Process Biochem 42:1571-1578 DOI: 10.1016/j. procbio.2007.05.026

Smacchi E, Gobbetti M, Rossi J, Fox PF (2000) Purification and characterization of a extracellular esterase from Arthrobacter nicotianae 9458. Lait 80:255-265

Sobek H, Görisch H (1988) Purification and characterization of a heat-stable esterase from the thermophilic archaebacterium Sulfolobus acidocaldarius. Biochem J 250:453-458

Tekedar H, Sanli-Mohamed G (2011) Molecular cloning, over expression and characterization of thermoalkalophilic esterases isolated from Geobacillus sp. Extremophiles 15:203-211. US EPA (2000) Vinyl acetate. Available at: http://www.epa.gov/ttn/atw/hlthef/ vinylace.html Accessed at 15 May 2012

US EPA (2000) Vinyl acetate. http://www.epa.gov/ttn/atw/hlthef/ vinylace.html Accessed at 15 May 2012

Yang CH, Liu WH (2008) Purification and properties of an acetylxylan esterase from Thermobifida fusca. Enzyme Microb Technol 42:181-186. doi:10.1016/j.enzmictec.2007.09.007

Zamost BL, Nielsen HK, Starnes RL (1991) Thermostable enzymes for industrial applications. J Ind Microbiol 8:71-82 